\title{
НАСЛЕДСТВЕННАЯ ПРАВОСПОСОБНОСТЬ ИНОСТРАННЫХ ГРАЖДАН И ОБЛАДАТЕЛЕЙ ДВОЙНОГО ГРАЖДАНСТВА
}

\begin{abstract}
Аннотация: Данная статья посвящена такому проблемному вопросу реализации наследственной правоспособности обладателей иностранного гражданства как наследование ими земельных участков принадлежащих к категории земель сельскохозяйственного назначения и земель находящихся на приграничных территориях. Это во многом формальное ограничение не применяется к обладателям двойного гражданства поскольку в соответствии с российским законодательством они рассматриваются как граждане России. Автором приводятся в пример аналогичные ограничения действующие в законодательстве Эстонской Республики и Кыргызской Республики. При написании данной статьи автор использовала метод сравнительно-правового исследования и историко-ретроспективного анализа. Кроме того, в настоящей статье используется способ доказательства как «доказательство от противного» Автором опровергается ставший расхожим тезис о том, что российское законодательство прямо запрещает лицам обладающим иностранным гражданством владеть на праве собственности земельным участком относящимся к землям сельскохозяйственного назначения или расположенным на приграничной территории. Поскольку данный, конкретный вывод сделан на основании общих норм законодательства, то очевидно, что сказанное в данной статье относительно земельных правоотномений можно применить и к иным общественным отношениям, правовое регулирование которых допускает ограничения прав участников, личный статут которых определяется правопорядком иностранного государства: корпоративных и трудовых отношений.

Abstract: This article focuses on the challenging issue related to the implementation of such hereditary legal capacity of foreign citizenship holders as inheritance of land belonging to the category of agricultural land and land located in the border areas. This largely formal restriction does not apply to holders of dual citizenship because under the Russian legislation they are considered as citizens of Russia. The author gives the example of similar restrictions operating in the Republic of Estonia and the laws of the Kyrgyz Republic. In writing this article, the author uses the method of comparative legal studies and historical retrospective analysis. Furthermore, this paper follows the method of "proof by contradiction". The author refutes the widespread thesis that the Russian law explicitly prohibits persons who have foreign citizenship to own land related to agricultural or located in the border area. Since this particular conclusion was based on the general rules of the legislation, it is clear that what is said in this article concerning land relations can be applied to other public relations, legal regulation of which permits restrictions on the rights of participants, personal statute of whom is defined by the rule of law of a foreign country, i.e. corporate and labor relationship.
\end{abstract}

Ключевые слова: наследование, завещание, иностранные граждане, бипатриды, апатриды, земельные участки, земли сельскохозяйственного назначения, правоспособность, дееспособность, иностранные юридические лица Keywords: inheritance, testament, foreign citizens, dual nationals, stateless persons, land, agricultural land, legal capacity, active capacity, foreign legal entities

ормы российского материального права, peгулирующие правовой режим наследования с участием иностранных субъектов не представляют собой стройной системы. Так, наследниками по завещанию могут в соответствии с п. 2 ст.1116 ГК РФ являться не только иностранные граждане, апатриды и иностранные юридические лица, но также иностранные государства и международные организации, тогда как в случае наследования по закону иностранные государства и международные организации лишены этого права. 
DOI: $10.7256 / 1811-9018.2014 .2 .10637$

При цитировании этой статьи сноска на dоі обязательна

\section{Право и политика $2(170) \cdot 2014$}

Поскольку никаких специальных норм регулирующих положение иностранных граждан в качестве сторон наследственных правоотношений российское законодательство не содержит, применяется общее правило ст. 4 Федерального закона от 25.07.2002 N 115-Ф3 «О правовом положении иностранных граждан в Российской Федерации» ${ }^{1}$ устанавливающей национальный режим, предполагающий равноправие иностранных граждан и граждан России в качестве наследников по закону и по завещанию. Последнее правило основано на ст. 62 Конституции РФ провозгласившей равноправие иностранных граждан и апатридов с гражданами Российской Федерации, кроме случаев специально указанных в федеральных законах и международных договорах.

К отношениям собственности иностранцев применимо и правило ч. 2 ст. 35 Конституции РФ, в соответствии с которым каждый вправе иметь имущество в собственности, владеть, пользоваться и распоряжаться им как единолично, так и совместно с другими лицами. Употребляя термин «каждый», Конституция распространяет данный принцип на любых лиц, в том числе на иностранцев ${ }^{2}$.

Предметом рассмотрения в данной статье является проблема наследования иностранными субъектами (физическими и юридическими лицами) земельных участков и прав участия в хозяйственных обществах (акционерных обществах и обществах с ограниченной ответственностью) осуществляющих стратегические виды деятельности.

Ограничение земельной правосубъектности иностранных субъектов традиционно для правовых систем многих государств. Так в соответствии с положениями статьи 32 Конституции Эстонской Республики 1992 г. указывается, что «в общих интересах законом могут быть установлены виды имущества, которые в Эстонии могут приобретать в собственность только граждане Эстонской Республики, юридические лица некоторых категорий, местные самоуправления или Эстонское государство». Статья 5 Земельного кодекса Кыргызской Республики, посвященная праву иностранных лиц на земельный участок, определяет, что предоставление и передача в собственность иностранным лицам сельскохозяйственных угодий не допускается. Кроме того, ч. 1 ст. 7 Закона Кыргызской Республики «Об управлении

\footnotetext{
${ }^{1}$ С3 РФ 29.07.2002, N 30, ст. 3032,
}

${ }^{2}$ Право собственности: актуальные проблемы / отв. ред. В.Н. Литовкин, Е.А. Суханов, В.В. Чубаров; Ин-т законод. и сравнит. правоведения. М.: Статут, 2008. $731 \mathrm{c}$. землями сельскохозяйственного назначения» предусматривает, что право собственности на землю, предоставление и передача в собственность земель сельскохозяйственного назначения в Кыргызской Республике запрещаются иностранным гражданам, юридическим лицам и государствам; лицам без гражданства, проживающим на территории Кыргызской Республики; совместным предприятиям; супругам, если один из них является гражданином иностранного государства либо лицом без гражданства. В Кыргызской Республике переход к иностранному лицу земельного участка сельскохозяйственного назначения в порядке универсального правопреемства влечет последствия, предусмотренные п. 2, 3 ст. 37 Земельного кодекса Кыргызской Республики. Если наследником сельскохозяйственных угодий является иностранное лицо, оно обязано в течение одного года с момента возникновения права на земельный участок произвести его отчуждение гражданину Кыргызской Республики. В случае, когда иностранным лицом не произведено отчуждение права на земельный участок, перешедшего к нему по наследству, отчуждение производится принудительно. Иностранным лицам, как физическим, так и юридическим земельные участки в черте населенного пункта (городов, поселков, сельских населенных пунктов) могут предоставляться на правах срочного (временного) пользования или передаваться в собственность в случае кредитования ими ипотечного жилищного строительства в соответствии с Законом Кыргызской Республики «О залоге». Иностранным лицам земельные участки вне населенных пунктов, за исключением сельскохозяйственных угодий, могут предоставляться на правах срочного (временного) пользования Правительством Кыргызской Республики. ${ }^{3}$

Юридическая способность иностранных граждан быть субъектами наследственных отношений в части передачи по наследству земельных участков на территории России неразрывно связана с правом собственности, поскольку в соответствии с российским законодательством, правом на передачу земельных участков по наследству обладают лишь их собственники и субъекты права пожизненного наследуемого владения ${ }^{4}$.

\footnotetext{
${ }^{3}$ Дихтяр А.И., Селифонова С.Ю. Ограничения прав иностранных лиц на земли сельскохозяйственного назначения: сравнительный анализ законодательства стран - участниц СНГ и ЕврАзЭС // Юридический мир. 2012. N 1. С. 49 - 51.

${ }^{4}$ Пожизненное наследуемое владение как ограниченное вещное право крайне слабо распространено, к тому же в соответствии с положениями реформы гражданского законодательства предполагается его полная ликвидация. 6 сентября 2013 года вступили в юридическую силу изменения в установленные Земельным кодексом РФ основания и порядок принудительного прекраще-
} 
Развитие земельной правосубъектности иностранных субъектов в современной России можно логически разделить на два этапа. На первом этапе становления российского законодательства происходила борьба между группировками сторонников тогдашнего Президента РФ, стоявших на либеральной позиции по данному вопросу, и сторонников национальнопатриотической идеологии (преимущественно представляющими партии КПРФ и ЛДПР). Законодательно закрепленный запрет на передачу иностранным субъектам земельных участков на праве собственности и на праве пожизненного наследуемого владения (п. 3 ст. 4 Закона РСФСР «О земельной реформе» от 23 ноября 1990г. ${ }^{5}$, ст. 4 Закона РСФСР «О крестьянском (фермерском) хозяйстве» от 22 ноября 1990г. ${ }^{6}$ и ст. 7 Земельного Кодекса РСФСР 1991г.) $)^{7}$ осуществлялся путем т.н. «указного правотворчества» ${ }^{8}$.

Исследуя данную проблему, А.П. Анисимов и А.И. Мелихов, отмечали что «первая брешь в запрещении иметь им земельный участок в собственности была пробита Президентом РФ, причем косвенным путем, используя приватизационное законодательство. Так, через приватизацию объектов государственной и муниципальной собственности, в которой российское законодательство не запрещало участвовать иностранным гражданам, лицам без гражданства и иностранным юридическим лицам, на основании Указов Президента РФ уже в 1992 г. начался выкуп ими земельных участков под приватизируемыми объектами в собственность»9.

Второй этап развития земельной правосубъектности берет свое начало с вступления в юридическую силу Земельного Кодекса РФ и Федерального закона «Об обороте земель сельскохозяйственного назначения». Земельный Кодекс РФ ограничил перечень нормативных правовых актов, ограничивающих действие принципа национального режима в сфере обладания правом собственности на земельные участки, во-первых, Земельным Кодексом РФ, а во-вторых, федеральными законами (п.2 ст.5).

ния права постоянного (бессрочного) пользования земельным участком, а также права пожизненного наследуемого владения земельным участком.

5 «Ведомости СНД и ВС РСФСР», 1990, N 26, ст. 327

${ }^{6}$ «Ведомости СНД и ВС РСФСР», 1990, N 26, ст. 324

${ }^{7}$ «Ведомости СНД и ВС», 30.05.1991, N 22, ст. 768

${ }^{8}$ Термин введен в оборот В.О.Лучиным

${ }^{9}$ Анисимов А.П., Мелихов А.И. О некоторых теоретических проблемах земельной правосубъектности иностранных граждан и юридических лиц// «Право и политика», 2005, N 6
Сам Земельный Кодекс РФ запрещает гражданам иностранных государств, апатридам и иностранным юридическим лицам обладать на праве собственности категориями земельных участков, находящихся:

А) на приграничных территория $\mathrm{x}^{10}$,

Б) на иных установленных особо территориях РФ.1

В свою очередь Федеральный закон «Об обороте земель сельскохозяйственного назначения» называет одним из принципов оборота земельных участков, принадлежащих к категории земель сельскохозяйственного назначения, соблюдение установленных законодательством РФ особенностей предоставления таких земельных участков иностранным гражданам и лицам без гражданства (пп. 5 п. 3 ст.1 данного Федерального закона).

Статья 3 этого нормативного акта ограничивает иностранным гражданам и юридическим лица, а также апатридам возможность владеть и пользоваться земельными участками земель сельскохозяйственного назначения только титулом аренды. Таким образом, иностранные граждане и лица без гражданства формально не могут выступать наследниками земельных участков из состава земель сельскохозяйственного назначения.

Принятие и передача земельных участков из земель сельскохозяйственного назначения в наследство иностранным гражданином или апатридом возможны. Однако это влечет за собой последствия, предусмотренные ст. 5 Федерального закона «Об обороте земель сельскохозяйственного назначения». Такие земельные участки должны быть отчуждены собственником в течение одного года с даты возникновения права собственности на них. Поскольку при их отчуждении необходимо соблюдение установленного тем же Федеральным законом преимущественного права и порядка приобретения земельных участков субъектом РФ, то при условии согласия данного субъекта на приобретение указанного земельного участка, иностранный гражданин или апатрид будет иметь преимущественное право на заключение договора аренды этого земельного участка.

\footnotetext{
${ }^{10}$ перечень приграничных территорий установлен Указом Президента РФ от 09.01.2011 N 26 «Об утверждении перечня приграничных территорий, на которых иностранные граждане, лица без гражданства и иностранные юридические лица не могут обладать на праве собственности земельными участками» (С3 РФ 10.01.2011, N 2, ст. 268). Нельзя не отметить того, что данный документ избрал формальный критерий отнесения территорий к приграничным - в качестве таковых в нем фигурируют в том числе территории, явно не соприкасающиеся с государственной границей Российской Федерации.

${ }^{11}$ Например, земельные участки в границах морского порта (п.2 ст. 28 Федерального закона от 08.11.2007 N 261-Ф3 «О морских портах в Российской Федерации и о внесении изменений в отдельные законодательные акты Российской Федерации»)
} 


\section{Право и политика $2(170) \cdot 2014$}

Несколько более дискуссионным является вопрос о возможности наследования земельных участков бипатридами - лицами обладающими двумя (или более) гражданствами.

Как уже было указано выше, действующее земельное законодательство содержит запрет для иностранных граждан на обладание на праве собственности земельными участками: а) относящимися к категории земель сельскохозяйственного назначения и б) земельными участками находящимися на приграничных территориях.

Конституция Российской Федерации 1993 года не содержит положений о запрете или о каких-либо ограничениях в приобретении двойного гражданства. Как верно указывает К.И. Налетов, «хотя ст. 62 Конституции РФ непосредственно разрешает его, как указано в ч.1 «в соответствии с федеральным законом или международным договором Российской Федерации», это отнюдь не означает фактического запрета наличия двойного гражданства вне рамок международного договора ратифицированного Россией $^{12}$. В случае отсутствия соответствующего международного договора, двойное гражданство лишь не признается в качестве специфического правового состояния, а его обладатели рассматриваются с точки зрения российского права не как бипатриды, но исключительно как граждане России в соответствии с положениями п.1 ст.6 Федерального закона «О гражданстве Российской Федерации» ${ }^{13}$.

В настоящее время такой договор подписан лишь с республикой Таджикистан (Договор между Российской Федерацией и Республикой Таджикистан об урегулировании вопросов двойного гражданства (Подписан в г. Москве 07.09.1995) $)^{14}$. Граждане иных государств, одновременно обладающие гражданством России, рассматриваются с точки зрения российского права исключительно как российские граждане. В подтверждение данной позиции можно привести положения ст.21 Закона РФ от 21.07.1993 N 5485-1 «О государственной тайне» ${ }^{15}$ и п. 3 Постановления Правительства РФ от 22.08.1998 N 1003 «Об утверждении Положения о порядке допуска лиц, имеющих двойное гражданство, лиц без гражданства, а также лиц из числа иностранных граждан, эмигрантов и

\footnotetext{
${ }^{12}$ Международное частное право. Учебник (под ред. Р.А. Курбанова и С.Н. Бабурина) М. Юрайт, 2013 (автор раздела - Налетов К.И.) С. 53

${ }^{13}$ Там же

${ }^{14}$ Дипломатический вестник. 1995. N 10. С. 24 - 26.

15 «Российская газета», N 182, 21.09.1993
}

реэмигрантов к государственной тайне» ${ }^{16}$ отдельно указывающие на а) лиц обладающих двойным гражданством и на б) иностранных граждан как на обладателей сведений, содержащих государственную тайну. Очевидно, что в случае, когда обладатели второго гражданства всегда рассматривались с точки зрения российского законодательства как иностранные граждане, смысл существования указания на бипатридов отсутствовал бы.

Формально, силами одного государства невозможно запретить обладание его гражданами другими гражданствами, поскольку это означало бы вмешательство во внутренние дела соответствующих иностранных государств ${ }^{17}$. Юридически являясь правопреемником СССР, Российская Федерация является участником двусторонних международных договоров направленных на недопущение двойного гражданства. Среди них можно назвать такие договоры как конвенция между Правительством СССР и Правительством Монгольской Народной Республики о предотвращении случаев возникновения двойного гражданства от 11 сентября 1975 года ${ }^{18}$, а также Договор между СССР и Чехословацкой Советской Социалистической Республикой о предотвращении возникновения двойного гражданства от 6 июня 1980 года ${ }^{19}$.

Однако указанный запрет, установленный для иностранных граждан, не распространяется на обладателей двойного гражданства, которые как показано выше рассматриваются как граждане России.

Таким образом, следует согласиться с позицией Налетова К.И. в том, что «отказ в предоставлении земельного участка на территории России на основании одного только факта обладания лицом помимо гражданства России, гражданством иного государства, неправомерен $\rangle^{20}$.

Российское гражданское законодательство неоднозначно решает вопрос о круге иностранных наследников. Так, в соответствии с его нормами иностранные государства и международные организации не являются наследниками по закону. Правом наследования $\mathrm{ad}$ hoc $^{21}$ их может наделить только сам наследодатель, составив завещание в их пользу.

\footnotetext{
${ }^{16}$ С3 РФ 31.08.1998, N 35, ст. 4407

${ }^{17}$ Международное частное право. Учебник (под ред. Р.А.Курбанова и С.Н. Бабурина) М. Юрайт, 2013 (автор раздела - Налетов К.И.)

${ }^{18}$ Ведомости ВС СССР. 25 апреля 1984. N 17. Ст. 284.

${ }^{19}$ Ведомости ВС СССР. 12 августа 1981 г. N 32. Ст. 950.

${ }^{20}$ Налетов К.И. Некоторые вопросы договора ренты// Гражданин и право - 2013. - № 7. - С. 47 -53.

${ }^{21}$ Однократно, в данном конкретном случае (лат)
} 
Что же касается иностранных граждан и лиц без гражданства (апатридов), то специальные нормы, регулирующие их правовой статус в качестве сторон наследования, в российском законодательстве отсутствуют. Конституция РФ 1993 года и Федеральный закон N 115-Ф3 «О правовом положении иностранных граждан в Российской Федерации» приравняли лиц, принадлежащих к обеим категориям, к гражданам РФ в смысле наследственной правосубъектности.

Исключением из принципа национального режима является правовое регулирование отношений в сфере наследования иностранными субъектами (физическими и юридическими лицами) земельных участков

Земельное законодательство (Земельный Кодекс РФ и Федеральный закон «Об обороте земель сельскохозяйственного назначения») содержит запрет иностранным лицам и лицам без гражданства иметь на праве собственности земельные участки, находящиеся на приграничных территориях, и земельные участки, принадлежащие к категории земель сельскохозяйственного назначения, независимо от их местонахождения. Однако, вывод о том, что перечисленные лица не могут выступать наследниками земельных участков верен лишь отчасти. Как принятие, так и передача земельных участков из земель сельскохозяйственного назначения по наследству иностранным лицом или лицом без гражданства возможны. Однако это влечет за собой последствия, предусмотренные ст. 5 Федерального закона «Об обороте земель сельскохозяйственного назначения». Такие земельные участки в обязательном порядке отчуждаются новым собственником в течение одного года с даты возникновения права собственности на них. При этом необходимо соблюдение преимущественного права субъекта РФ на приобретение данного земельного участка и соблюдение права иностранного гражданина (лица без гражданства) преимущественного права на заключение договора аренды, непосредственным предметом которого является этот земельный участок.

Что же касается обладателей двойного гражданства, то поскольку они рассматриваются в качестве граждан Российской Федерации, то на них перечисленные ограничения не распространяются.

\section{Библиография:}

1. Дихтяр А.И., Селифонова С.Ю. Ограничения прав иностранных лиц на земли сельскохозяйственного назначения: сравнительный анализ за- конодательства стран-участниц СНГ и ЕврАзЭС // Юридический мир. 2012. N 1. С. 49-51.

2. Анисимов А.П., Мелихов А.И. О некоторых теоретических проблемах земельной правосубъектности иностранных граждан и юридических лиц//»Право и политика», 2005, N 6

3. Налетов К.И. Некоторые вопросы договора ренты// Гражданин и право - 2013. - № 7.

4. Цыганков А.В. Проблемы законодательного регулирования, обеспечивающего реализацию социально-экономических прав и свобод иностранных граждан и лиц без гражданства в Российской Федерации // Актуальные проблемы российского права. - 2009. - 3. - С. 129-133.

5. Цыганков А.В. К вопросу о совершенствовании понятийного аппарата законодательства Российской Федерации о правовом положении иностранных граждан и лиц без гражданства // Актуальные проблемы российского права. - 2009. - 4. - С. 66-70.

6. Мамитова Н.В. Миграционная политика Российской Федерации: проблемы теории и практики // NB: Проблемы общества и политики. - 2013. - 6. - C. 73-104. URL: http://www.e-notabene.ru/pr/ article_532.html

7. Смирнова Е.С. Проблемы пребывания иностранных граждан на территории государства и вопросы обеспечения их безопасности // NB: Международное право. - 2013. - 2. - С. 39 - 66. URL: http://www.e-notabene.ru/wl/article_676.html

\section{References (transliteration):}

1. Dikhtyar A.I., Selifonova S.Yu. Ogranicheniya prav inostrannykh lits na zemli sel'skokhozyaistvennogo naznacheniya: sravnitel'nyi analiz zakonodatel'stva stran-uchastnits SNG i EvrAzES // Yuridicheskii mir. 2012. N 1. S. 49-51.

2. Anisimov A.P., Melikhov A.I. O nekotorykh teoreticheskikh problemakh zemel'noi pravosub"ektnosti inostrannykh grazhdan i yuridicheskikh lits//»Pravo i politika», 2005, N 6

3. Naletov K.I. Nekotorye voprosy dogovora renty// Grazhdanin i pravo - 2013. - № 7.

4. Tsygankov A.V. Problemy zakonodatel'nogo regulirovaniya, obespechivayushchego realizatsiyu sotsial'no-ekonomicheskikh prav i svobod inostrannykh grazhdan i lits bez grazhdanstva v Rossiiskoi Federatsii // Aktual'nye problemy rossiiskogo prava. - 2009. - 3. - C. 129-133. 
DOI: $10.7256 / 1811-9018.2014 .2 .10637$

При цитировании этой статьи сноска на dоі обязательна

\section{Право и политика $2(170) \cdot 2014$}

5. Tsygankov A.V. K voprosu o sovershenstvovanii ponyatiinogo apparata zakonodatel'stva Rossiiskoi Federatsii o pravovom polozhenii inostrannykh grazhdan i lits bez grazhdanstva // Aktual'nye problemy rossiiskogo prava. - 2009. - 4. - C. 66-70.

6. Mamitova N.V. Migratsionnaya politika Rossiiskoi Federatsii: problemy teorii i praktiki // NB: Problemy obshchestva i politiki.-2013.-6.-C. 73-104. URL: http:// www.e-notabene.ru/pr/article_532.html

7. Smirnova E.S. Problemy prebyvaniya inostrannykh grazhdan na territorii gosudarstva i voprosy obespecheniya ikh bezopasnosti // NB: Mezhdunarodnoe pravo. -2013. - 2. - C. 39-66. URL: http://www.e-notabene. ru/wl/article_676.html 